\title{
Development of urban transport infrastructure with the use of mechanized multi-level parking systems
}

\author{
Olga Manukhina ${ }^{1, *}$ \\ ${ }^{1}$ Moscow State University of Civil Engineering, Yaroslavskoye sh., 26, 129337, Moscow, Russia
}

\begin{abstract}
In the article various variants of the decision of such acute problem, as shortage of parking places in system of a city infrastructure are considered. The necessity and expediency of constructing high-speed mechanized car parks for cars is caused by the acute problem of temporary and permanent storage of vehicles in the conditions of large cities, in places of intensive human flows such as the central part of the city, supermarkets, railway stations, shopping centers, as well as business centers and residential sector cities. To date, most of the real estate (residential buildings, hotels, offices, shopping and entertainment and multifunctional centers) are built with standard parking spaces. During the operation of such standard parking lots, the developer understands that the number of cars exceeds the number of parking spaces provided in the parking lot. The shortage of parking spaces and free parking areas significantly increases the importance of the construction and arrangement of multi-level parking lots. The system of high-altitude automatic parking lots offers a serious alternative to the generally accepted ideas about parking of vehicles [1].
\end{abstract}

\section{Introduction}

The lack of free territories and space is a big problem in the development of urban infrastructure, especially in the conditions of already established dense urban development. One of the most relevant and economically viable solutions to this problem is the use of technology to automate parking [1]. This technology contributes to the achievement of economic efficiency and is very beneficial for the developer. Among other things, the use of this technology opens a wide range of possibilities in the design of objects of varying complexity [2].

The method of parking used in multi-level systems was developed by A.F. Vishnevsky. The essence of this method consists in the arrangement of cars in rows in which the longitudinal axes of parked cars are parallel to each other. Since the placement of vehicles is carried out in pairs, there is a decrease in the distance between neighboring pairs of cars. The process of increasing the density of the location of vehicles in parking lots is schematically reflected in Fig 1.

\footnotetext{
${ }^{*}$ Corresponding author: dek508@mgsu.ru
} 


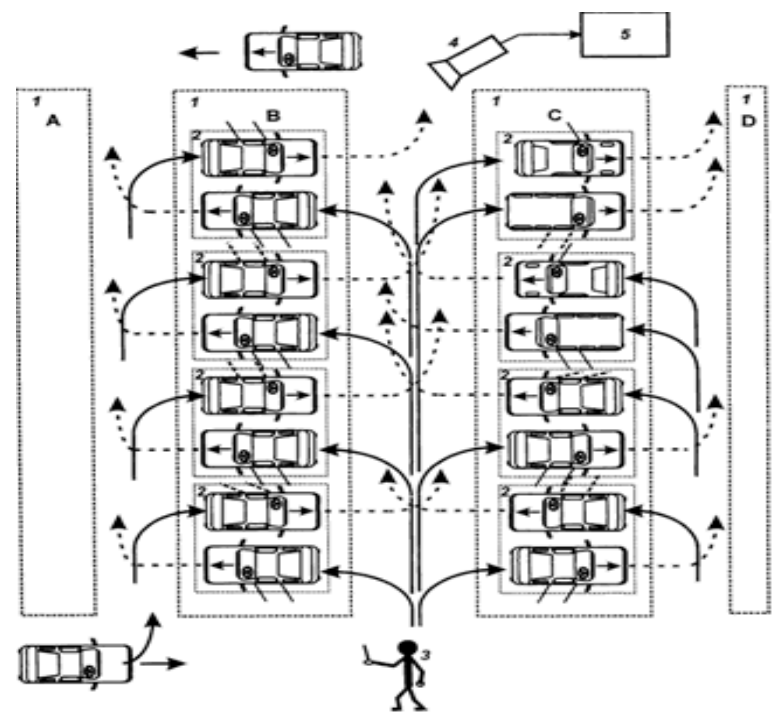

Fig. 1. The method of placing vehicles to reduce the distance between vehicles.

The most widespread for today classification of car parkings (parking space) has the following appearance:

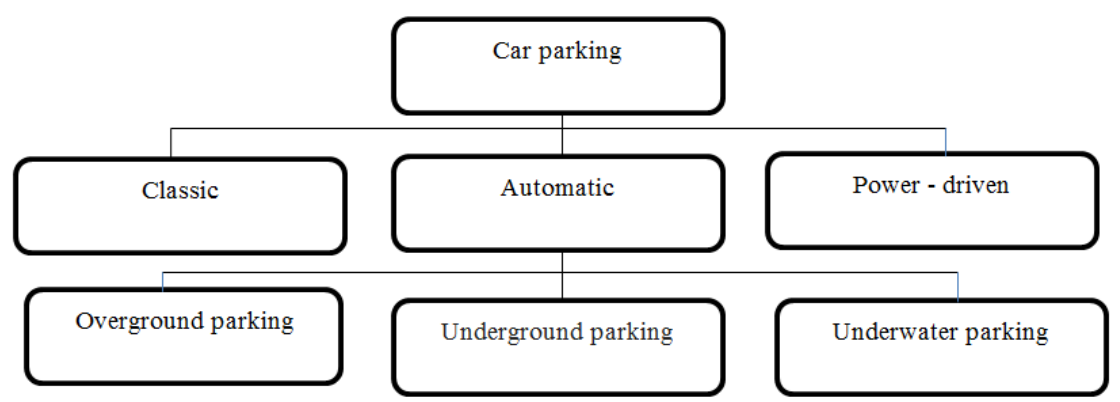

Fig. 2. Classification of car parkings (parking space).

Considering various constructive mechanisms of the automated systems of a parking of vehicles it is possible to classify them as follows:

1) By mobility of storage sites:

- with stationary places of storage (the process of moving cars between the terminals of the system produces a special mechanized device);

- with movable lots (if necessary, the place of storage of the car automatically moves inside the parking lot) [3].

2) On the design of the elements of the capture of cars:

- with vehicle tracking devices (a pallet system is used to ensure the accumulation and storage of pallets near the terminal);

- without a vehicle tracking device (automated movement is carried out using plate, roller or belt conveyors, installed, as a rule, under each pair of wheels of the car).

3) By mutual arrangement of storage locations:

- with a parallel method of storage;

- with a consistent method of storage;

- with a radical way of storing.

4) If possible, simultaneous execution of various operations by the device: 
- with a sequential circuit of the automatic device;

- with a parallel circuit of the automatic device;

- with the mixed scheme of operation of the automatic device.

5) By type of access to storage locations: with direct and indirect access, where indirect access is accompanied by a short-term removal of the foreground obstacles (cars, pallets) [4].

As a practical example of the application of this technology, we can cite a multi-level parking project, led by Lanovoy A.T. architect, member of the Union of Moscow Architects, general director of the design bureau "NABAD Design". In the implementation of this project, inclined floors were used for the first time, ensuring the free movement of vehicles within the parking system according to the simplest and safest scheme. The use of large-span slabs allowed to minimize the number of supports and get rid of the "dead zones", which limit the output of the total area to one car place.

Currently, there is a large number of existing patents, both for project approaches to automatic parking, and for individual elements of it. The patent most fully reflecting the essence of automatic parking belongs to Closed Joint Stock Company "Transport Mission". This parking system differs from others by the fact that it contains a central (water) heat supply system, the installation of "thermal electric guns", as well as a control system that is interfaced with the systems of electro-automatics and console equipment, hoisting, environmental control and ventilation, automatic fire extinguishing, automatic control of overall dimensions - weight characteristics of the car, protection, registration and control of parked cars and automatic gates [5-6].

At present, parking spaces are complex architectural structures that combine innovative technologies for servicing cars with the latest construction solutions in the field of construction.

One of the most acute problems of modern conditions of multi-apartment building is costly solutions to the problem of locating vehicles.

\section{Result section}

To date, one of the traditional solutions to this problem is the forced diversion of large tracts of land to parking lots for motor vehicles of residents and their guests. This solution to the problem - the placement of vehicles in the local areas significantly reduces the economic effect of using the land allocated for building [7].

Another traditional solution for the location of vehicles by the developer is the construction of a reinforced concrete multi-level parking (Fig. 3). This option requires a long-term investment of cash. Often the cost of parking spaces in such parking lots is high and complete their sale, and therefore, their full payback is extended for a long period of time. The use of mechanized parking allows the developer to allocate a much smaller area for installation in the future of mechanized parking, and purchase equipment if there is real demand and payment from the consumer. This becomes possible, as the period of manufacture and installation of parking is $4-6$ months. This solution allows the developer not to "freeze" large funds to build a parking lot, but use financial resources with a large economic effect [8].

Trying to adapt for underground and underwater construction traditional multi-tiered garages is inefficient due to the cumbersome, small utilization rate of space $(35-40 \mathrm{~m} 2 / 1$ car) and the high cost of one car parking lot. 

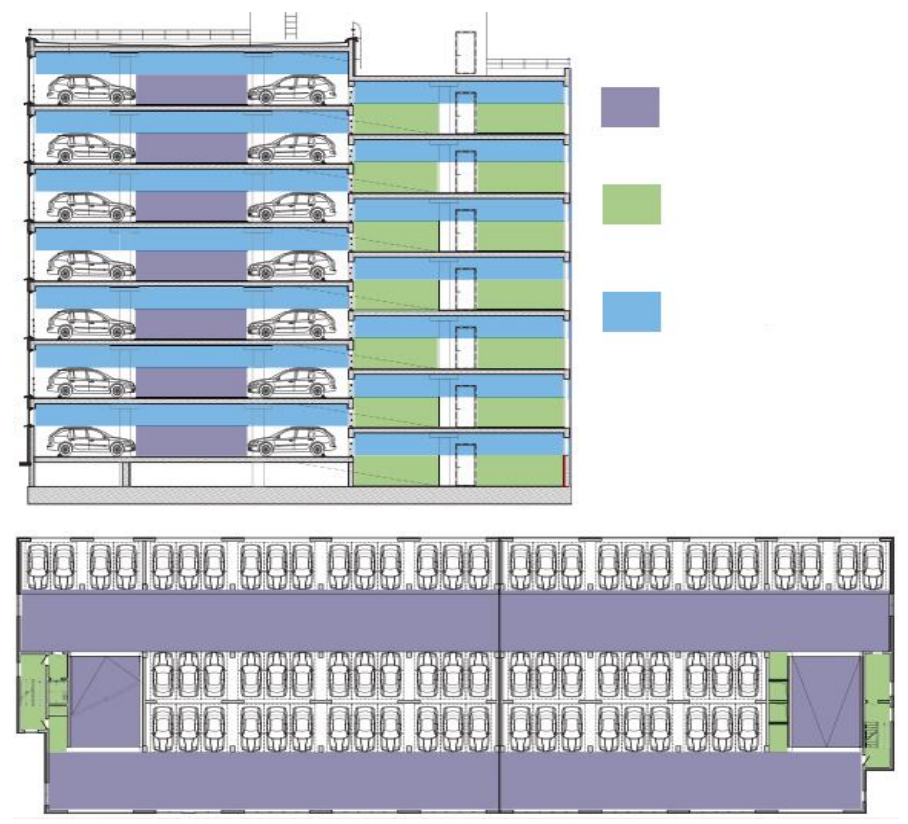

Fig. 3. Type of classic reinforced concrete parking.

The multi-level automatic parking system (MAP) is a system consisting of several levels of metal or concrete structures / structures for the storage of cars. Parking and delivery of cars in this system is carried out automatically, using various mechanized devices. The movement of the car inside the parking lot takes place with the engine of the car turned off and without the presence of a person. In comparison with traditional parking lots, the use of automatic parking allows to minimize the area necessary for parking [9]. Figure 4 shows a comparative analysis of the capacity of various types of parking (Fig. 4).

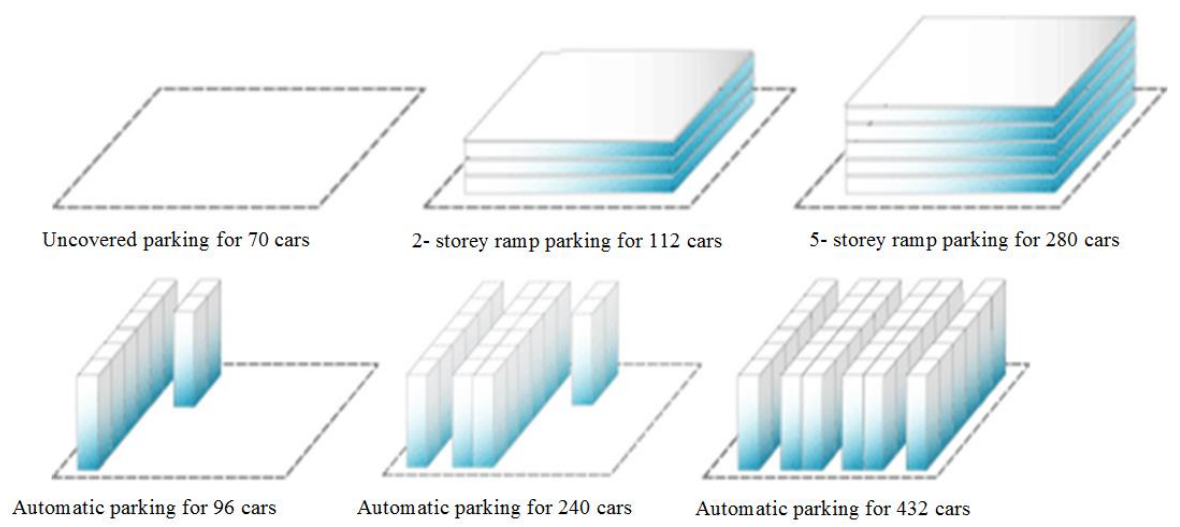

Fig. 4. Comparison of the spaciousness of parking lots (at least).

Parking, with the use of mechanized (robotic) devices, are divided into the following types:

1) Multi-tiered automatic parking, in which parking and car delivery are fully automatic. In such parking lots, the driver enters the reception compartment, turns off the engine and leaves, after which the robotic conveyors automatically move the car in the parking lot, delivering it to the desired storage cell in the parking system [10]. 
Multi- tiered automatic parking lots can be of the following several types:

- Tower type - the principle of operation is based on the movement of a high-speed lift in the tower, on both sides of which there are pallets with cars. One of the most compact parking towers occupies an area of only 3 parking spaces $(50-60 \mathrm{~m} 2)$, and the number of parking spaces in it is limited only to the normative height of development in the area and can reach up to 80 cars (Fig. 5).

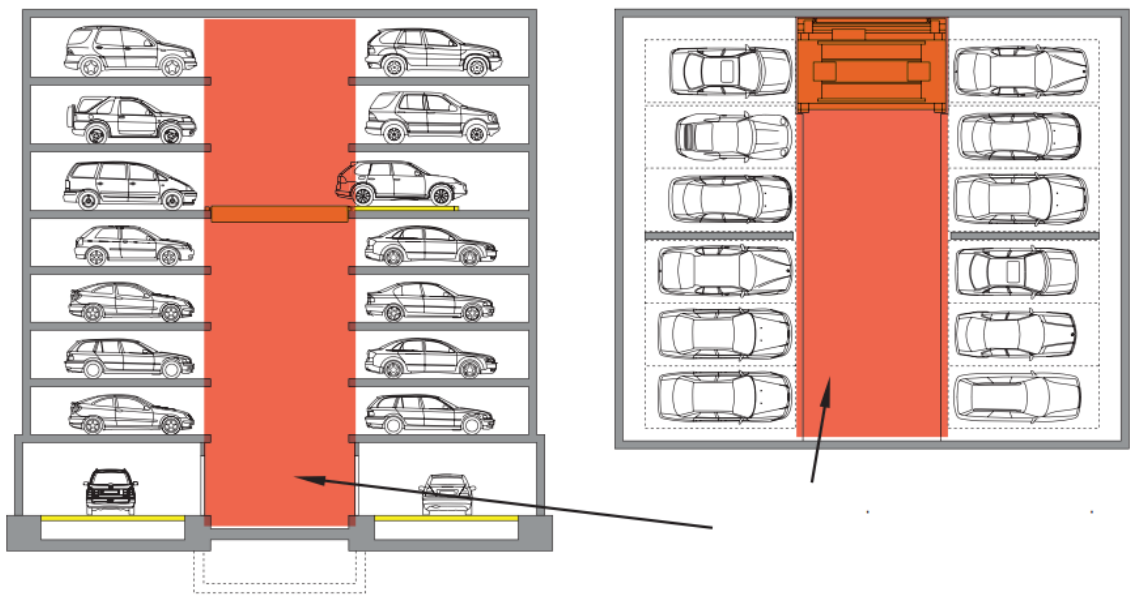

Fig. 5. Automatic tower parking system.

- Cassette (conveyor) type of parking - is based on the operation of mechanisms similar to the principle of the conveyor (horizontal movement of pallets of the same level), on both sides of which are elevators moving vertically [11-12]. This parking system is recommended for small and medium sized parking spaces, limited in width (Fig. 6).
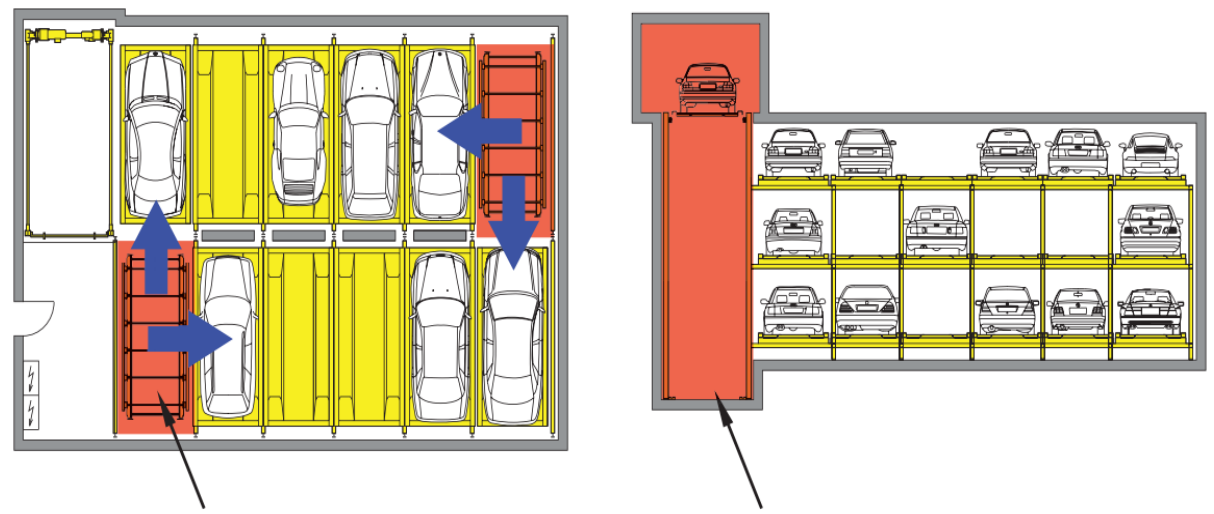

Fig. 6. Conveyor type parking system.

- Robotic type of parking - its working principle consists in the operation of vertically moving lifts and horizontally moving robots-conveyors working simultaneously on different levels. Robotic type of parking is the most suitable option for medium and large parking spaces.

2) Many-tier semi-automatic (mechanical / mechanized) parking - the principle of operation of this type of parking is based on the fact that the driver does not drive into the reception compartment, as in automatic parking, but directly to the pallet located in the mechanical parking construction, which is the storage cell of the car in the parking system. 
The parking system moves the pallet, freeing up empty space with the inside of the car, or transporting a particular car for delivery from the parking system [13].

Depending on the variant of the movement of the storage cells of the car (pallets), such parking lots can be subdivided into the following types:

- Rotary (carousel) type, the mechanism of which is based on the principle of a large carousel, where the logical control controller independently chooses the optimal way of delivery of the car, while rotating the mechanism in one direction or another

- Puzzled (mosaic) type - the principle of this type of work is based on the alternate movement of pallets vertically and horizontally into a vacant cell [14].

\section{Conclusions}

It must be noted that the advantages of the mechanized parking systems produced by the company "MIKO" are attractive both for the car owner and for the builder.

Table 1. Comparative characteristics of the advantages of mechanized multi-level parking lots, produced by OOO MIKO [5].

\begin{tabular}{|c|c|}
\hline Advantages for the owner of the vehicle & Advantages for the developer \\
\hline $\begin{array}{l}\text { Ability to park the car in walking distance from the } \\
\text { place of residence; } \\
\text { The price of a parking space is much lower than the } \\
\text { place in a traditional parking lot; } \\
\text { By means of individual means of identification (key, } \\
\text { coded magnetic or electronic card, infrared means and } \\
\text { remote controls), unauthorized access by unauthorized } \\
\text { persons is excluded; } \\
\text { Operational safety (there is no need to enter narrow } \\
\text { dark roads and return through uncomfortable ladders); } \\
\text { The ability to easily adapt to various projects due to the } \\
\text { wide variety and versatility of equipment; } \\
\text { High degree of protection of motor vehicles against } \\
\text { atmospheric, technogenic pollution and other damages; } \\
\text { The high quality of the equipment is confirmed by the } \\
\text { relevant quality certificates of producing countries and } \\
\text { GOST R. }\end{array}$ & $\begin{array}{l}\text { The presence of mechanized multi-level parking } \\
\text { eliminates the need for long-term investment of } \\
\text { funds in the construction of traditional parking; } \\
\text { Increase of parking spaces } 9 \text { times; } \\
\text { Low power consumption - } 1 \text { cycle (parking + } \\
\text { delivery) } \approx 1 \mathrm{~kW} \text { / h; } \\
\text { The use of buried foundations is not required (in } \\
\text { comparison with ground parking) } \\
\text { If necessary, it is possible to change the location of } \\
\text { the mechanized multi-level parking: } \\
\text { There is no need to install expensive lighting and } \\
\text { ventilation systems; } \\
\text { Lack of ramps and access roads; } \\
\text { Low noise level (less than } 30 \mathrm{~dB} \text { ), allows to install } \\
\text { the system close to the building (permissible } \\
\text { standard noise level } 60 \mathrm{~dB} \text { ); } \\
\text { Low noise level (less than } 30 \mathrm{~dB} \text { ), allows to install } \\
\text { the system close to the building (permissible } \\
\text { standard noise level } 60 \mathrm{~dB} \text { ); } \\
\text { Aesthetic component (it is possible to use } \\
\text { decorative materials in the facade decoration) }\end{array}$ \\
\hline
\end{tabular}

The rationality of these types of automatic parking is that it is possible to receive and issue simultaneously several cars at different levels depending on the architectural solution [15]. Parking systems have high capacity and fast service. To minimize the cost of parking time.

\section{References}

1. I. Bahirev, S. Kanep, Karmadonova N.Town planning 5 (39), 20-23 (2015)

2. N. Danilina, D. Vlasov, MATEC Web of Conferences 5, 05017 (2016)

3. S. Okhotina, P. Kukhtin, L. Manukhina, MATEC Web of Conferences 106, 08074 (2017)

4. M. Sharov, A. Mikhailov, Transportation Research Procedia, 591-595 (2017)

5. D. Vlasov, E3S Web of Conferences, 01012 (2016) 
6. A.G. Levashev, A.Yu. Mikhailov, I.M. Golovnykh, WIT Transactions on Ecology and the Environment 2, 1067 (2013)

7. O. Kurakova, MATEC Web of Conferences 170, 01105 (2018)

8. I. Bahirev, Arhitektura. Stroitel'stvo. Dizajn 3, 60-63 (2008)

9. A. Menshutin, D. Vlasov, N. Danilina, The development of intermodal transport services on the basis of geoanalytical information, ITM Web of Conferences (2016)

10. N. Danilina, E3S Web of Conf. Series: International Conference on Sustainable Cities, ICSC 2016, 02001 (2016)

11. M. Kostyshak, M. Lunyakov, IOP Conf. Series: Energy Management of Municipal Transportation Facilities and Transport 19, 012183 (2017)

12. I. Bahirev, Transport construction 10, 2-5 (2008)

13. A. Levashev, A. Mikhailov, I. Golovnykh, WIT Transactions on Ecology and the Environment 179(2), 1067-1076 (2014)

14. V. Karpov, A. Panin, A. Semenov, Transportation Research Procedia, 261-266 (2017)

15. S. Repin, S. Maksimov, V. Golovko, V. Kuzmichev, Transportation Research Procedia, 556-563 (2017) 